\title{
World Bank cracks down on cultural damage
}

\section{Rex Dalton, Tucson}

The World Bank is close to adopting a rigorous new policy that aims to safeguard archaeological and anthropological sites that could be affected by its development projects.

A policy drafted by bank officials calls for early assessment of cultural heritage resources in areas to be developed, and requires the borrowing nation to address the need to preserve physical resources. It also provides for emergency measures to conserve valuable sites.

Within a month, the board of the bank one of the world's main backers of development projects - is expected to vote on the draft, which was agreed after three years of consultation with scientists and other interested parties.

Bank officials also hope that its new stance will prompt other agencies that fund development projects to embrace stronger policies to protect cultural heritage.

"The policy is potentially revolutionary," says Steven Brandt, a University of Florida archaeological anthropologist who sits on the bank's eight-person scientific advisory panel. "The bank is really sincere about this," he says.
Researchers hope the policy will also lead to training and placement of archaeologists and anthropologists in the countries where development projects are going forward. Many poor nations, especially in Africa, have few such scientists of their own.

But while the World Bank moves to adopt its new policy, researchers at last month's biennial meeting of the Society of Africanist Archaeologists in Tucson, Arizona, reported that significant problems persist with development projects now in progress.

In Ethiopia, for instance, Brandt says that scientists and volunteers are rushing to complete a last-minute cultural heritage assessment of an area near Jimma - where a reservoir is soon to be filled as part of the \$300-million Gilgel Gibe hydroelectric dam project, funded by the World Bank and the European Union (EU).

Brandt says that EU-funded roads for the project have been bulldozed through ancient cemeteries, infuriating local people and scientists. EU and bank officials declined to comment.

Scientists have only been able to muster about \$200,000 for surveys of the reservoir and surrounding area in southwest Ethiopia,

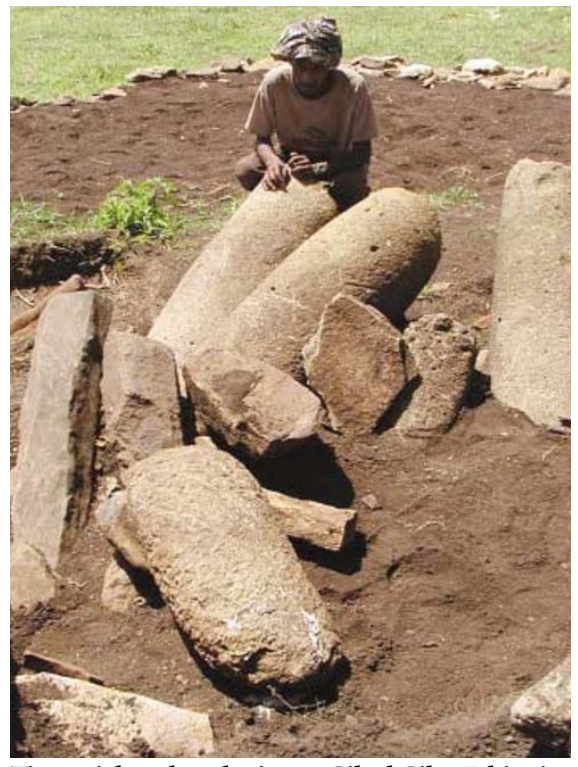

Time trial: archaeologists at Gilgel Gibe, Ethiopia, are racing to survey the site before a dam is built.

according to Brandt. "It has been a real scramble and nightmare," he says.

t worldbank.org

twwww.nilebasin.org

\section{British science champion quits post}

David Adam, London

A body charged with improving science communication in Britain is looking for new leadership after its illustrious chairperson resigned, complaining angrily about its lack of progress in meeting its goal.

Bridget Ogilvie, former head of the Wellcome Trust, the world's largest medical research charity, accused the Royal Society of blocking her attempts to turn the body, called Copus, into an umbrella organization for the various UK groups involved in science communication.

"To become an umbrella organization it has to be an organization where not one body dominates, but the Royal Society runs Copus and is not prepared to allow Copus to evolve," Ogilvie said. "Frankly I've got better things to do with my time." She announced her decision to surprised colleagues at the organization's spring council meeting on 17 May.

Formerly known as the Committee on the Public Understanding of Science, Copus was launched in 1985 by the Royal Society, the Royal Institution and the British Association. It was remodelled last year to include representatives from other organizations, including scientific societies, museums and the media, but effectively remains a branch of

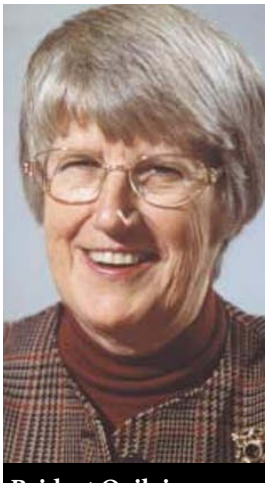

the Royal Society, which applies for government funds on its behalf and provides offices.

Ogilvie says she wanted Copus to evolve into a more democratic body in which member organizations are each able to exert roughly equal influence. But Bridget Ogilvie: move stunned colleagues.

Stephen Cox, executive secretary of the Royal Society and a member of the Copus council, says that would not work because groups interested in science communication don't have the cash to support Copus in that way. "Currently we provide Copus with its home and infrastructure and as soon as you spin it off, all those costs have to be found from somewhere else," he says.

Other Copus council members question the need for an 'umbrella' organization. "We're all too busy with our own agendas to stand around keeping the rain off each other," says Jon Burch, executive secretary of the Royal Academy of Engineering.

\section{Uncertainty ends for US nuclear lab as new leader is named}

Rex Dalton, San Diego

A new director has been appointed at the Lawrence Livermore National Laboratory (LLNL) in California - ending weeks of uncertainty over the future leadership of the nuclear-weapons research facility.

Physicist Michael Anastasio, currently LLNL's deputy director for strategic operations, was approved as director on 4 June by the regents of the University of California (UC), which manages the lab for the US Department of Energy.

Anastasio has worked at LLNL for 22 years, and is said to have played a key role in maintaining the safety and reliability of nuclear weapons in the absence of testing. He will take over from the current director, Bruce Tarter, on 1 July. LLNL has 7,500 employees and an annual budget of around $\$ 1.5$ billion.

In April,Anastasio was one of a shortlist of four candidates when the UC regents almost named nuclear engineer Ray Juzaitis, an associate director at Los Alamos National Laboratory in New Mexico, as LLNL director. But that plan was abandoned, reportedly after some LLNL researchers voiced opposition to it (see Nature 417, 3; 2002). 